\title{
Long-term administration of bisphosphonate to reduce local recurrence of sacral giant cell tumor after nerve-sparing surgery
}

\author{
*Wei Xu, MD, ${ }^{1}$ Yu Wang, MD, ${ }^{2}$ Jing Wang, MD, ${ }^{1}$ Xinghai Yang, MD, ${ }^{1}$ Weibo Liu, MD, ${ }^{3}$ \\ Wang Zhou, MD, ${ }^{1}$ Tielong Liu, MD, ${ }^{1}$ and Jianru Xiao, MD' \\ ${ }^{1}$ Department of Orthopedic Oncology, Changzheng Hospital, Second Military Medical University, Shanghai; ${ }^{2}$ Department of Spine \\ Surgery, First Affiliated Hospital of Wenzhou Medical University, Zhejiang; and ${ }^{3}$ Department of Spine Surgery, Qingdao Central \\ Hospital, Qingdao, Shandong, China
}

\begin{abstract}
OBJECTIVE The objective of this study was to investigate the effect of long-term bisphosphonate treatment on reducing local recurrence of sacral giant cell tumors (GCTs) after nerve-sparing surgery.

METHODS Thirty-five consecutive patients with sacral GCTs who received treatment in Shanghai Changzheng Hospital between January 2000 and December 2010 were included in this study. Between January 2007 and December 2010, 19 patients received bisphosphonates following nerve-sparing surgery. Before January 2007, 16 patients received nervesparing surgery alone, and these cases were included as the control group. The difference in clinical data between the groups was compared by Student's t-test and 2-tailed chi-square or Fisher's exact test. The postoperative recurrencefree survival (RFS) and overall survival (OS) rates were estimated by the Kaplan-Meier method and compared between the groups by log-rank test. A p value $<0.05$ was considered statistically significant.
\end{abstract}

RESULTS All of the patients had relatively good nerve function. The clinical data were homogeneous between the groups. The local recurrence rate was 10.53\% (2 of 19) in the bisphosphonate treatment group and $43.75 \%$ (7 of 16$)$ in the control group. The log-rank test showed that the 3-year RFS and 3-year OS in the bisphosphonate treatment group were significantly higher than those in the control group (RFS $89.5 \%$ vs $56.3 \%, p=0.04$; OS $100 \%$ vs $81.3 \%, p=0.05$ ). CONCLUSIONS The long-term use of bisphosphonates after nerve-sparing surgery is a viable option for the treatment of sacral GCTs. This approach could reduce local recurrences while preserving nerve function.

https://thejns.org/doi/abs/10.3171/2016.10.SPINE151197

KEY WORDS giant cell tumor; sacrum; recurrence-free survival; overall survival; nerve-sparing surgery; bisphosphonate; oncology; sacral

$\mathrm{G}$ IANT cell tumor (GCT) of bone is one of the most common tumors, accounting for approximately $3 \%-5 \%$ of all primary bone tumors. ${ }^{4,17}$ It usually occurs in the 3rd decade of life, predominantly in the female sex. The sacrum is the fourth most common site of all GCTs in the reported series, ranging from $2 \%$ to $8 \%{ }^{4,15,28}$ Clinically, sacral GCTs often present with few symptoms in the early stage of development, and tend to be quite large and vascular when diagnosed, ${ }^{14}$ rendering treatment extremely difficult.

Although classified as benign, GCTs can be associated with potentially aggressive behavior. ${ }^{7,8}$ Prevention of local recurrence is a major clinical challenge in the management of sacral GCTs. Although en bloc resection could reduce the recurrence rate, it can be associated with technical difficulties and a high risk of postoperative morbidity and nerve sacrifice. ${ }^{15}$ Intralesional curettage and piecemeal resection may better preserve the nerve function, but it is associated with a high local recurrence rate of $30 \%-50 \% .^{11,24}$

In a retrospective study, ${ }^{27}$ Tse et al. suggested that bisphosphonates could be used as an adjuvant therapy to reduce the local recurrence rate of GCTs of the extrem-

ABBREVIATIONS GCT = giant cell tumor; OS = overall survival; $\mathrm{PAE}=$ preoperative selective artery embolism; $\mathrm{PAR}=$ postoperative adjuvant radiotherapy; $\mathrm{RFS}=$ recurrence-free survival.

SUBMITTED October 7, 2015. ACCEPTED October 7, 2016.

INCLUDE WHEN CITING Published online March 24, 2017; DOI: 10.3171/2016.10.SPINE151197.

* Drs. W. Xu, Y. Wang, and J. Wang contributed equally to this work. 
ity after surgery. However, the effect of bisphosphonates in preventing sacral GCT recurrence has not been confirmed. The aim of this study was to investigate the effect of long-term bisphosphonate treatment after nerve-sparing surgery in reducing local recurrence of sacral GCTs.

\section{Methods}

\section{Study Design and Patients}

A retrospective study was performed to investigate the effect of long-term bisphosphonate treatment after nervesparing surgery in reducing local recurrence of sacral GCTs. Nerve-sparing surgery is the resection of the tumor by curettage or the piecemeal method, with preservation of the bilateral S-1, S-2, and at least the unilateral S-3 nerve roots. The surgical field was cleaned to the extent that no visible residual tumor cell was detected under the magnifier. The final diagnosis of GCT was made according to the pathological diagnosis after surgery.

After resection of the tumor, specimens were fixed in $10 \%$ formalin, embedded in paraffin, sliced into sections, and stained with standard $\mathrm{H} \& \mathrm{E}$. The final pathological diagnosis was confirmed by a pathologist with 15 years of experience. Inclusion criteria were as follows: 1) patients with pathologically diagnosed GCTs; 2) patients whose GCTs involved the sacrum; 3) patients who received nerve-sparing resection; 4) patients who were admitted to our center with the diagnosis of primary GCT; and 5) patients whose surgical procedures were performed by the same team of spinal tumor surgeons.

Between January 2000 and December 2010, 35 consecutive patients who met the inclusion criteria were enrolled in the study. Of them, 16 consecutive patients who underwent surgical treatment alone without receiving bisphosphonate treatment (i.e., before January 2007) were included as the control group. Zoledronic acid (4 mg) was not available in our center until January 2007, and incadronate disodium $(10 \mathrm{mg})$ was not available until October 2009. Therefore, the other 19 consecutive patients with primary sacral GCTs, who received nerve-sparing surgery between January 2007 and December 2010, were included in the bisphosphonate treatment group. Of them, 7 patients received zoledronic acid $(4 \mathrm{mg})$, and the other 12 patients received incadronate disodium $(10 \mathrm{mg})$ intravenously. An initial dose of bisphosphonate was given to each patient preoperatively, and for a two-year period after surgery, patients received 1 dose at 4 -week intervals. The adverse effects, if any, were recorded. Renal function was monitored in all patients before each infusion.

The tumors were staged according to the Enneking staging system. ${ }^{9}$ The neurological function was recorded, including the urinary, bowel, and ambulatory functions. Preoperative selective artery embolism (PAE) was performed to reduce intraoperative blood loss. All surgical procedures were performed through a posterior approach by the senior author (J.X.). Cisplatin and methotrexate were used as local treatment in cases in which the dura mater was not breached during the surgery. Cisplatin was applied to soak the surgical field by dissolving it in glucose solution. Methotrexate wrapped in Gelfoam was used as a filler following excision of the lesion. ${ }^{29}$ Three months after surgery, postoperative adjuvant radiotherapy (PAR) was administered. The prescribed dose was 45-50 Gy. After a comprehensive and detailed explanation to the patients and families about the risks, benefits, and costs of radiotherapy, the patients and their families decided to either follow or not follow the recommendation for radiotherapy.

\section{Follow-Up Study}

Each patient was followed on an outpatient basis every 3 months for the first 6 months, every 6 months for the subsequent 1.5 years, and yearly thereafter. Signs of local recurrence and metastasis and the neurological status were recorded at each follow-up visit. The diagnosis of local recurrence was confirmed by pathological evaluation in patients who received a second surgery. In suspected cases that did not receive a second surgery, the diagnosis of recurrence was based on the clinical manifestations, imaging findings, and signs of disease progression.

Recurrence-free survival (RFS) was defined as the interval between the date of surgery and the date of recurrence. Overall survival (OS) was defined as the interval between the date of the initial surgery and the date of death. Lung metastasis was diagnosed by clinical manifestations, chest radiographs, and chest CT findings. The neurological status, including the urinary, bowel, and ambulatory functions, was also recorded. The follow-up period was defined as the interval between the date of surgery and the date of death, or until December 2013 in patients without GCT recurrence.

\section{Statistical Analyses}

All statistical calculations were performed using PASW Statistics version 18.0 (IBM). Continuous data were compared by Student's t-test. Associations between categorical data were verified by 2-tailed chi-square or Fisher's exact test. The postoperative RFS and OS rates were estimated by the Kaplan-Meier method, and differences between the bisphosphonate-treated and control groups were analyzed using the log-rank test. ${ }^{12}$ A p value $<0.05$ was considered statistically significant.

\section{Ethical Considerations}

Written informed consent was obtained from all patients. The research was approved by Shanghai Changzheng Hospital's ethics committee, and a waiver for individual patient consent for this study was obtained.

\section{Results}

A total of 35 patients with sacral GCTs were enrolled in the study, with a mean age of $32.8 \pm 10.4$ years (median 31.0 years; range $15-56$ years). All of the GCTs were primary and involved the cephalic part of the sacrum (S-1 and S-2). Nerve-sparing surgery was performed to excise the tumor. The mean follow-up was 47.2 \pm 9.6 months (median 46.0 months; range 36-77 months) in the bisphosphonate treatment group and $92.1 \pm 43.6$ months (median 83.0 months; range 21-168 months) in the control group.

Of the 35 patients, GCT recurrence was pathologically confirmed in 9 patients; 2 in the bisphosphonate-treated 
group and 7 in the control group. Of the 9 patients with recurrent GCT, 1 patient received bisphosphonate treatment following the first recurrence, after which no further recurrence was observed. The mean time from surgery to the first recurrence was $12.7 \pm 9.4$ months (median 9.0 months; range 3-44 months). All 9 patients with recurrent GCT developed the first recurrence within 3 years after surgery. Three patients died as the result of disease progression 25, 36, and 21 months, respectively, after the initial surgery. The neurological functions of the patients who died as the result of disease progression were not evaluated. Of the 32 surviving patients, $26(81.3 \%)$ patients had good neurological function with normal urinary, bowel, and ambulatory functions. Two patients suffered from urinary incontinence, and 1 patient from powerlessness over urinary function. One patient had bowel incontinence, 2 patients had constipation, and 1 patient was unable to walk without a stick after the surgery. Details are shown in Table 1.

\section{Comparisons of Clinical Data Between Bisphosphonate Treatment and Control Groups}

The clinical data were homogeneous between the bisphosphonate treatment and control groups (Table 2). There were no significant differences in age $(\mathrm{p}=0.88)$, sex $(\mathrm{p}=1.00)$, or duration from symptom onset to the diagnosis $(\mathrm{p}=0.68)$ between the groups. Thirteen cases were classified as Enneking Stage 3 and 6 cases as Enneking Stage 2 in the bisphosphonate-treated group, versus 14 cases as Enneking Stage 3 and 2 cases as Enneking Stage 2 in the control group. There was no significant difference in Enneking stage between the groups $(p=0.24)$. Of the 19 patients in the bisphosphonate treatment group, 17 received PAE, 18 received intraoperative chemotherapy, and 13 received PAR. Of the 16 patients in the control group, 13 received PAE, 12 received intraoperative chemotherapy, and 10 received PAR. There were no significant differences in the rates of PAE $(p=0.64)$, intraoperative chemotherapy $(p=0.16)$, and PAR $(p=0.74)$ between the groups.

\section{Effects of Bisphosphonates on Reducing Local Recurrence of Sacral GCT}

The local recurrence rate was $10.53 \%$ (2 of 19) in the bisphosphonate treatment group and $43.75 \%$ (7 of 16) in the control group. The log-rank test showed that the 3-year RFS rate was significantly increased in the bisphosphonate treatment group $(\mathrm{p}=0.04)$ (Fig. 1). The 3-year OS rate was 100\% (19 of 19) in the bisphosphonate-treated group and $81.3 \%$ (13 of 16) in the control group. The difference in the 3-year OS rate between the bisphosphonate-treated and control groups was significant $(\mathrm{p}=0.05)$ (Fig. 2).

\section{Discussion}

Giant cell tumor is a locally aggressive tumor of bone. The sacrum is the fourth most common site for GCTs. The onset of symptoms is generally insidious. Patients with GCT most frequently complain of a slowly progressive problem over several months; ${ }^{20}$ as a result, the GCT is not diagnosed until it becomes quite large. The present study showed that patients with sacral GCT most frequently complained of local pain over a mean period of 7 months. Most patients presented with sacral GCT classified as Enneking Stage 3, and all of the GCTs in our series involved the S-1 and S-2 segments.

Complete resection remains the mainstay treatment for GCTs and is very successful in long-bone lesions, with a recurrence rate as low as $10 \% .{ }^{17}$ However, surgical treatment of sacral GCTs is particularly difficult because of their relatively advanced clinical presentation and surrounding anatomical structures. Some studies have reported that en bloc resection of sacral GCTs could minimize the possibility of local recurrence. Sar and Eralp ${ }^{23}$ found no recurrence during follow-up of 31-203 months in 7 patients with sacral GCTs who received en bloc resection. Martin and McCarthy ${ }^{15}$ found no recurrence during follow-up of 14-55 months in 2 patients with sacral GCTs who received en bloc resection. In a large series of 37 patients with sacral GCTs who received en bloc resection, recurrence developed in 11 (29.7\%) patients. ${ }^{30}$ In addition to the difficulties in technique, this treatment often requires sacrifice of the sacral nerve roots and is associated with potentially severe morbidity. ${ }^{15}$ Preserving the bilateral S-1 nerve roots is essential for keeping the patient's normal gait and foot plantar flexion. Patients may suffer from bowel and bladder dysfunction when unilateral S-2 or bilateral S-3 nerve roots are sacrificed. ${ }^{3,11,18,26}$

Taking into account the nerve function and the postoperative quality of life, we treated 16 patients with nervesparing surgery between 2000 and 2006. In these cases, the tumor was resected by curettage or the piecemeal method, with preservation of bilateral $\mathrm{S}-1, \mathrm{~S}-2$, and at least the unilateral S-3 nerves. All of the patients had good nerve function after surgery. However, in these procedures, in which the tumors are entered, there are possibly residual tumor cells in the wound. ${ }^{4}$ Also, there is greater potential for leaving microscopic tumors after curettage or piecemeal excision if the sacral nerve roots are preserved. ${ }^{22}$ As a result, the recurrence rate may be $>50 \% .^{11,24}$ We cleaned the surgical field to the extent that no visible residual tumor cell was detected under the magnifier, and cisplatin and methotrexate were used intraoperatively to kill residual cells. In our series, the local recurrence rate was $43.75 \%$ after nerve-sparing surgery. How to reduce local recurrence while preserving the nerve function is a clinical dilemma.

Bisphosphonate is a nontoxic analog of pyrophosphate and is known to inhibit osteoclast-mediated bone resorption. Histologically, GCT consists of osteoclast-like multinucleated giant cells, mononuclear cells, and stromal cells. ${ }^{12,16}$ It has been proven that bisphosphonate can kill GCT stromal and osteoclast-like cells in studies in vivo. ${ }^{5,6}$ Balke et al. ${ }^{1}$ reported a study in 9 patients with sacral GCTs who were treated by bisphosphonates without surgery. The tumors remained almost unchanged in size in 6 patients, disease progression was observed in 1 patient, and a decrease in tumor size was observed in only 1 patient, indicating that bisphosphonate alone is not a viable option and can be used only in unresectable cases. Tse et al. ${ }^{27}$ reported their experience with the use of bisphosphonates for preventing GCT recurrence in the extremities after surgery. They found that the recurrence rate in the 
TABLE 1. Clinical data of a series of 35 cases of sacral GCT treated with nerve-sparing surgery

\begin{tabular}{|c|c|c|c|c|c|c|c|c|c|c|c|c|c|c|c|c|}
\hline $\begin{array}{l}\text { Case } \\
\text { No. }\end{array}$ & $\begin{array}{l}\text { Age, } \\
\text { Yrs }\end{array}$ & Sex & $\begin{array}{l}\text { ODD, } \\
\text { mos }\end{array}$ & ES & Site & PAE & IC & RT & BIS & $\begin{array}{c}\text { Recurrence, } \\
\text { No. (mos } \\
\text { postop) }\end{array}$ & $\begin{array}{c}\text { Metastasis } \\
\text { (mos } \\
\text { postop) }\end{array}$ & $\begin{array}{l}\text { FU, } \\
\text { Mos }\end{array}$ & $\begin{array}{l}\text { Urinary } \\
\text { Function }\end{array}$ & $\begin{array}{l}\text { Bowel } \\
\text { Function }\end{array}$ & $\begin{array}{l}\text { Ambulatory } \\
\text { Function }\end{array}$ & $\begin{array}{l}\text { Disease } \\
\text { Status }\end{array}$ \\
\hline 1 & 45 & $\mathrm{~F}$ & 2 & 3 & S2-5 & Y & $M$ & $Y$ & ZA & 0 & $\mathrm{~N}$ & 77 & Normal & Normal & Normal & NED \\
\hline 2 & 24 & M & 5 & 3 & S1-5 & Y & $\mathrm{N}$ & $\mathrm{Y}$ & $Z A$ & 0 & $\mathrm{~N}$ & 47 & $\begin{array}{l}\text { Incontinence } \\
\text { during sleep }\end{array}$ & Normal & Normal & NED \\
\hline 3 & 46 & M & 9 & 2 & S1-3 & Y & $C$ & $Y$ & $Z A$ & 0 & $\mathrm{~N}$ & 61 & Normal & Normal & Normal & NED \\
\hline 4 & 27 & M & 3 & 2 & $\mathrm{~S} 1-5$ & Y & $C$ & $Y$ & ZA & $2(3,15)$ & Lung (15) & 42 & Normal & Normal & Walk w/ stick & NED \\
\hline 5 & 22 & $\mathrm{~F}$ & 2 & 3 & S2-5 & Y & $C$ & $Y$ & ZA & $1(7)$ & $\mathrm{N}$ & 48 & Normal & Normal & Normal & NED \\
\hline 6 & 25 & $\mathrm{~F}$ & 4 & 3 & S2-3 & Y & $C$ & $Y$ & $Z A$ & 0 & $\mathrm{~N}$ & 40 & Normal & Normal & Normal & NED \\
\hline 7 & 31 & $\mathrm{~F}$ & 25 & 2 & S1-5 & Y & $C$ & $Y$ & ZA & 0 & $\mathrm{~N}$ & 58 & Normal & Normal & Normal & NED \\
\hline 8 & 16 & $\mathrm{~F}$ & 1 & 3 & S1-5 & $Y$ & $C$ & $Y$ & ID & 0 & $\mathrm{~N}$ & 47 & Normal & Normal & Normal & NED \\
\hline 9 & 41 & $\mathrm{~F}$ & 0.5 & 3 & S1-4 & Y & $C$ & $\mathrm{~N}$ & ID & 0 & $\mathrm{~N}$ & 47 & Normal & Normal & Normal & NED \\
\hline 10 & 28 & $\mathrm{~F}$ & 6 & 3 & S1-3 & Y & $C$ & $Y$ & ID & 0 & $\mathrm{~N}$ & 46 & Normal & Normal & Normal & NED \\
\hline 11 & 36 & M & 8 & 3 & S2-4 & $\mathrm{N}$ & $C$ & $\mathrm{~N}$ & ID & 0 & $\mathrm{~N}$ & 41 & Normal & Normal & Normal & NED \\
\hline 12 & 35 & M & 6 & 3 & S1-2 & $Y$ & $C$ & $\mathrm{~N}$ & ID & 0 & $\mathrm{~N}$ & 49 & Normal & Normal & Normal & NED \\
\hline 13 & 56 & M & 24 & 3 & S1-3 & Y & $C$ & $\mathrm{~N}$ & ID & 0 & $\mathrm{~N}$ & 46 & Normal & Normal & Normal & NED \\
\hline 14 & 32 & $\mathrm{~F}$ & 6 & 3 & S1-3 & $Y$ & $C$ & $\mathrm{~N}$ & ID & 0 & $\mathrm{~N}$ & 40 & Normal & Normal & Normal & NED \\
\hline 15 & 37 & $\mathrm{~F}$ & 8 & 2 & S1-2 & $Y$ & $C$ & $\mathrm{~N}$ & ID & 0 & $\mathrm{~N}$ & 44 & Normal & Normal & Normal & NED \\
\hline 16 & 27 & $\mathrm{~F}$ & 4 & 2 & S1-2 & $Y$ & $C$ & $Y$ & ID & 0 & $\mathrm{~N}$ & 50 & Normal & Normal & Normal & NED \\
\hline 17 & 21 & M & 2 & 3 & S1-3 & $Y$ & $C$ & $Y$ & ID & 0 & $\mathrm{~N}$ & 39 & Normal & Normal & Normal & NED \\
\hline 18 & 52 & $\mathrm{~F}$ & 7 & 2 & S1-2 & $\mathrm{N}$ & $C$ & $Y$ & ID & 0 & $\mathrm{~N}$ & 38 & Normal & Normal & Normal & NED \\
\hline 19 & 36 & $\mathrm{~F}$ & 5 & 3 & S1-4 & Y & $C$ & $Y$ & ID & 0 & $\mathrm{~N}$ & 36 & Normal & Normal & Normal & NED \\
\hline 20 & 18 & M & 4 & 3 & S1-3 & $Y$ & $M$ & $\mathrm{~N}$ & $\mathrm{~N}$ & 0 & $\mathrm{~N}$ & 126 & Normal & Normal & Normal & NED \\
\hline 21 & 41 & $\mathrm{~F}$ & 6 & 3 & S1-5 & Y & $M$ & $Y$ & $\mathrm{~N}$ & $1(32)$ & $\mathrm{N}$ & 113 & Incontinence & Constipation & Normal & NED \\
\hline 22 & 38 & M & 0.5 & 2 & $\mathrm{~S} 1-5$ & Y & $\mathrm{N}$ & $\mathrm{N}$ & $\mathrm{N}$ & 0 & $\mathrm{~N}$ & 131 & Normal & Normal & Normal & NED \\
\hline 23 & 33 & M & 2 & 3 & S1-3 & Y & $M$ & $\mathrm{~N}$ & $\mathrm{~N}$ & $2(9,44)$ & $\mathrm{N}$ & 80 & Powerless & Normal & Normal & AWD \\
\hline 24 & 31 & M & 2 & 3 & S1-5 & Y & $M$ & $Y$ & $\mathrm{~N}$ & 0 & $\mathrm{~N}$ & 97 & Normal & Incontinence & Normal & NED \\
\hline 25 & 15 & $\mathrm{~F}$ & 3 & 3 & S1-3 & Y & $C$ & $\mathrm{~N}$ & $\mathrm{~N}$ & $2(6,9)$ & $\mathrm{N}$ & 82 & Normal & Normal & Normal & NED \\
\hline 26 & 45 & $\mathrm{~F}$ & 6 & 3 & S1-2 & Y & $M$ & $Y$ & $\mathrm{~N}$ & $2(7,10)$ & $\mathrm{N}$ & 25 & - & - & - & DOD \\
\hline 27 & 48 & M & 5 & 3 & S1-2 & Y & $M$ & $Y$ & $\mathrm{~N}$ & 0 & $\mathrm{~N}$ & 156 & Normal & Normal & Normal & NED \\
\hline 28 & 31 & $\mathrm{~F}$ & 48 & 3 & S1-5 & $\mathrm{N}$ & $M$ & $Y$ & $\mathrm{~N}$ & 0 & $\mathrm{~N}$ & 70 & Normal & Constipation & Normal & NED \\
\hline 29 & 22 & $\mathrm{~F}$ & 3 & 3 & S2-5 & Y & $M$ & $\mathrm{~N}$ & $\mathrm{~N}$ & 0 & $\mathrm{~N}$ & 83 & Normal & Normal & Normal & NED \\
\hline 30 & 27 & $\mathrm{~F}$ & 4 & 3 & S1-3 & Y & M & $Y$ & $\mathrm{~N}$ & $1(23)$ & Lung (23) & 36 & - & - & - & DOD \\
\hline 31 & 44 & $\mathrm{~F}$ & 8 & 2 & S2-3 & $\mathrm{N}$ & $\mathrm{N}$ & $Y$ & $\mathrm{~N}$ & 0 & $\mathrm{~N}$ & 83 & Normal & Normal & Normal & NED \\
\hline 32 & 19 & $\mathrm{~F}$ & 3 & 3 & S1-2 & Y & $\mathrm{N}$ & $Y$ & $\mathrm{~N}$ & 0 & $\mathrm{~N}$ & 131 & Normal & Normal & Normal & NED \\
\hline 33 & 28 & $\mathrm{~F}$ & 4 & 3 & S2-3 & $\mathrm{N}$ & $\mathrm{N}$ & $Y$ & $\mathrm{~N}$ & 0 & $\mathrm{~N}$ & 168 & Normal & Normal & Normal & NED \\
\hline 34 & 29 & $F$ & 5 & 3 & S1-3 & Y & $M$ & $\mathrm{~N}$ & $\mathrm{~N}$ & $1(12)$ & No record & 21 & - & - & - & DOD \\
\hline 35 & 41 & $\mathrm{~F}$ & 2 & 3 & S1-3 & Y & $M$ & $Y$ & $Z A^{*}$ & $1(15)$ & $\mathrm{N}$ & 71 & Normal & Normal & Normal & NED \\
\hline
\end{tabular}

$\mathrm{AWD}=$ alive with disease; $\mathrm{BIS}=$ bisphosphonate; $\mathrm{C}=$ cisplatin; $\mathrm{DOD}=$ died of disease; $\mathrm{ES}=$ Enneking stage; $\mathrm{FU}=$ follow-up; $\mathrm{IC}=$ intraoperative chemotherapy; $I D=$ incadronate disodium; $\mathrm{M}$ = methotrexate; $\mathrm{N}=$ no; $\mathrm{NED}=$ no evidence of disease; $\mathrm{ODD}=$ onset to diagnosis duration; $\mathrm{RT}$ = radiotherapy; $\mathrm{Y}=$ yes; $\mathrm{ZA}=\mathrm{zoledronic}$ acid .

* The patient began to use the zoledronic acid after the second surgery.

bisphosphonate-treated group decreased to $4.2 \%$, which was significantly $<30 \%$ in the control group. However, the effect of bisphosphonates on preventing postoperative recurrence of sacral GCTs has not been evaluated.

In this study, bisphosphonates were given to 19 patients with sacral GCTs who received nerve-sparing surgery between 2007 and 2010. All of the patients had good nerve function after surgery. The 3-year RFS rate in the bisphosphonate-treated group was significantly higher than in the control group. Our results support the combination of nerve-sparing surgery and long-term bisphosphonate treatment as an efficient strategy to reduce local recurrence while preserving nerve function. Also, bisphosphonate treatment could increase the 3 -year OS rate.

In the present study, we used the 3-year RFS and OS rates as the outcome measure for the following reasons. 1) The patients who received bisphosphonate treatment were followed for a mean of $47.2 \pm 9.6$ months (median 46.0 months; range 36-77 months). 2) All 9 patients with recurrent GCTs developed the first recurrence within 3 years 
TABLE 2. Comparison of clinical data between bisphosphonatetreated and control groups

\begin{tabular}{|c|c|c|c|}
\hline Factor & $\begin{array}{l}\text { BIS-Treated } \\
\text { Group }\end{array}$ & Control Group & $\mathrm{p}$ Value \\
\hline Period & $\begin{array}{l}\text { Jan } 2007 \text { to } \\
\text { Dec } 2010\end{array}$ & $\begin{array}{l}\text { Jan } 2000 \text { to } \\
\text { Dec } 2006\end{array}$ & - \\
\hline No. of subjects & 19 & 16 & - \\
\hline Mean age in yrs \pm SD & $33.5 \pm 10.8$ & $31.9 \pm 10.2$ & 0.88 \\
\hline $\operatorname{Sex}(M / F)$ & $7: 12$ & $5: 11$ & 1.00 \\
\hline $\begin{array}{l}\text { Onset symptom (pain/ } \\
\text { neurological deficit) }\end{array}$ & $16 / 3$ & $15 / 1$ & 0.38 \\
\hline Mean ODD in mos \pm SD & $6.7 \pm 6.7$ & $6.6 \pm 11.2$ & 0.68 \\
\hline Enneking stage (3/2) & $13 / 6$ & $14 / 2$ & 0.24 \\
\hline $\mathrm{PAE}(\mathrm{Y} / \mathrm{N})$ & $17 / 2$ & $13 / 3$ & 0.64 \\
\hline $\begin{array}{l}\text { Chemotherapy during } \\
\text { surgery }(\mathrm{Y} / \mathrm{N})\end{array}$ & $18 / 1$ & $12 / 4$ & 0.16 \\
\hline Adjuvant RT (Y/N) & $13 / 6$ & $10 / 6$ & 0.74 \\
\hline
\end{tabular}

after surgery. 3) Three patients died as the result of disease progression 25, 36, and 21 months, respectively, after the initial surgery.

Bisphosphonate has been used as a treatment for various bone disorders and has proven to be a well-tolerated drug. ${ }^{2,21}$ In this study, we suggested 1 dose of bisphosphonate at 4-week intervals after surgery for 2 years, knowing that most GCT recurrences have occurred within 2 years after surgery. ${ }^{11,15}$ Of 19 patients treated with bisphosphonates, 7 were treated with zoledronic acid and 12 were treated with incadronate disodium. We found that the 2 patients in the bisphosphonate-treated group who had recurrent disease both received zoledronic acid treatment.

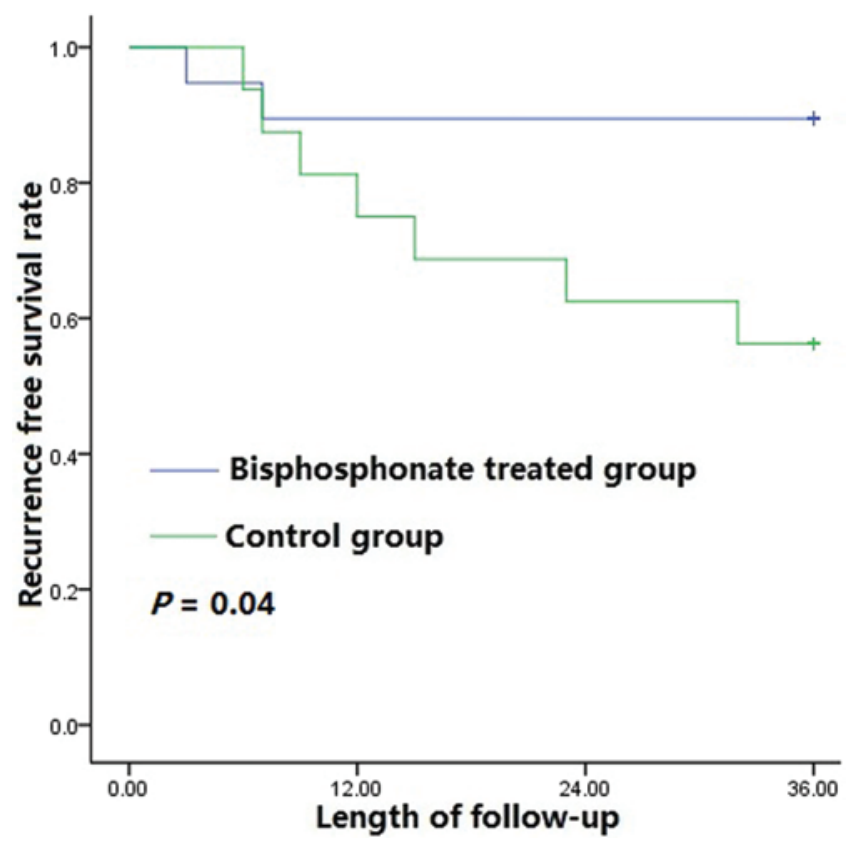

FIG. 1. Kaplan-Meier curves of 3-year RFS between the bisphosphonate-treated and control groups. Length of follow-up is shown in months. Figure is available in color online only.

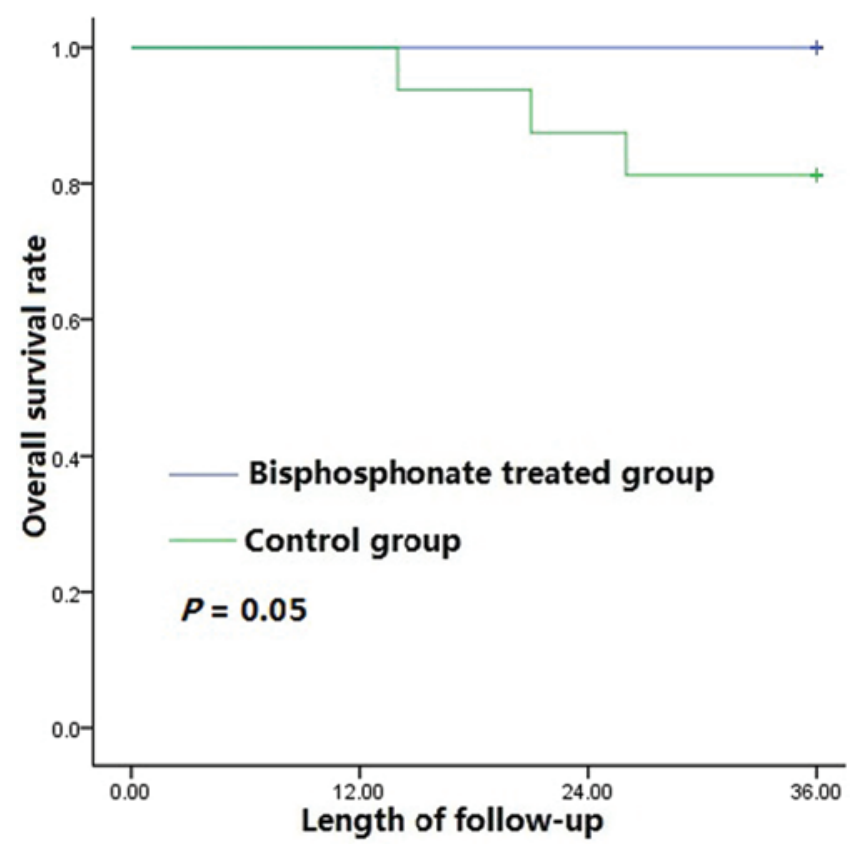

FIG. 2. Kaplan-Meier curves of 3-year OS between the bisphosphonatetreated and control groups. Length of follow-up is shown in months.

Figure is available in color online only.

But it is hard to conclude which bisphosphonate is better due to the small number of patients in the 2 subgroups in this study. The method of drug delivery should be further investigated.

Although no patient in our series suffered significant adverse events, it should be noted that long-term use of a bisphosphonate may be associated with some severe complications. ${ }^{19}$ Denosumab, a monoclonal antibody that is specific to the receptor activator of nuclear factor kappa-B ligand (RANKL), has been reported to be a safe targetedtherapeutic method. ${ }^{10,13}$ It has been used in recurrent and unresectable GCTs, with encouraging outcomes..$^{25}$ Whether denosumab could be used to prevent local recurrence of GCTs has not been established. Therefore, further studies are needed to explore the potential value of denosumab in the management of sacral GCTs.

This study has several limitations. First, it is a retrospective study, and the results may be associated with some potential bias. Second, the power of the statistical tests was not strong enough due to the relatively small sample size. A well-designed randomized control trial with long-term follow-up is needed to more clearly identify the value of bisphosphonates in the management of sacral GCTs.

\section{Conclusions}

Long-term use of bisphosphonates combined with nerve-sparing surgery seems to be a viable option for the treatment of sacral GCTs. This approach could reduce local recurrences while preserving nerve function.

\section{Acknowledgments}

This study was supported by the Shanghai Youth Science and Technology Talent Sailing program (Grant 14YF1405900). 


\section{References}

1. Balke M, Campanacci L, Gebert C, Picci P, Gibbons M, Taylor R, et al: Bisphosphonate treatment of aggressive primary, recurrent and metastatic giant cell tumour of bone. BMC Cancer 10:462, 2010

2. Berenson JR, Lichtenstein A, Porter L, Dimopoulos MA, Bordoni R, George S, et al: Long-term pamidronate treatment of advanced multiple myeloma patients reduces skeletal events. J Clin Oncol 16:593-602, 1998

3. Biagini R, Ruggieri P, Mercuri M, Capanna R, Briccoli A, Perin S, et al: Neurologic deficit after resection of the sacrum. Chir Organi Mov 82:357-372, 1997

4. Campanacci M, Baldini N, Boriani S, Sudanese A: Giant-cell tumor of bone. J Bone Joint Surg Am 69:106-114, 1987

5. Chang SS, Suratwala SJ, Jung KM, Doppelt JD, Zhang HZ, Blaine TA, et al: Bisphosphonates may reduce recurrence in giant cell tumor by inducing apoptosis. Clin Orthop Relat Res (426):103-109, 2004

6. Cheng YY, Huang L, Lee KM, Xu JK, Zheng MH, Kumta SM: Bisphosphonates induce apoptosis of stromal tumor cells in giant cell tumor of bone. Calcif Tissue Int 75:71-77, 2004

7. Dahlin DC: Caldwell Lecture. Giant cell tumor of bone: highlights of 407 cases. AJR Am J Roentgenol 144:955960,1985

8. Eckardt JJ, Grogan TJ: Giant cell tumor of bone. Clin Orthop Relat Res (204):45-58, 1986

9. Enneking WF: A system of staging musculoskeletal neoplasms. Clin Orthop Relat Res (204):9-24, 1986

10. Fizazi K, Carducci M, Smith M, Damião R, Brown J, Karsh $\mathrm{L}$, et al: Denosumab versus zoledronic acid for treatment of bone metastases in men with castration-resistant prostate cancer: a randomised, double-blind study. Lancet 377:813822,2011

11. Guo W, Ji T, Tang X, Yang Y: Outcome of conservative surgery for giant cell tumor of the sacrum. Spine (Phila Pa 1976) 34:1025-1031, 2009

12. Gamberi G, Benassi MS, Ragazzini P, Pazzaglia L, Ponticelli F, Ferrari C, et al: Proteases and interleukin- 6 gene analysis in 92 giant cell tumors of bone. Ann Oncol 15:498-503, 2004

13. Henry DH, Costa L, Goldwasser F, Hirsh V, Hungria V, Prausova J, et al: Randomized, double-blind study of denosumab versus zoledronic acid in the treatment of bone metastases in patients with advanced cancer (excluding breast and prostate cancer) or multiple myeloma. J Clin Oncol 29:1125-1132, 2011

14. Lin PP, Guzel VB, Moura MF, Wallace S, Benjamin RS, Weber KL, et al: Long-term follow-up of patients with giant cell tumor of the sacrum treated with selective arterial embolization. Cancer 95:1317-1325, 2002

15. Martin C, McCarthy EF: Giant cell tumor of the sacrum and spine: series of 23 cases and a review of the literature. Iowa Orthop J 30:69-75, 2010

16. McDonald DJ, Sim FH, McLeod RA, Dahlin DC: Giant-cell tumor of bone. J Bone Joint Surg Am 68:235-242, 1986

17. Mendenhall WM, Zlotecki RA, Scarborough MT, Gibbs CP, Mendenhall NP: Giant cell tumor of bone. Am J Clin Oncol 29:96-99, 2006

18. Nakai S, Yoshizawa H, Kobayashi S, Maeda K, Okumura Y: Anorectal and bladder function after sacrifice of the sacral nerves. Spine (Phila Pa 1976) 25:2234-2239, 2000

19. Otto S, Sotlar K, Ehrenfeld M, Pautke C: Osteonecrosis of the jaw as a possible rare side effect of annual bisphosphonate administration for osteoporosis: a case report. J Med Case Reports 5:477, 2011

20. Randall RL: Giant cell tumor of the sacrum. Neurosurg Focus 15(2):E13, 2003
21. Rosen LS, Gordon D, Kaminski M, Howell A, Belch A, Mackey J, et al: Long-term efficacy and safety of zoledronic acid compared with pamidronate disodium in the treatment of skeletal complications in patients with advanced multiple myeloma or breast carcinoma: a randomized, double-blind, multicenter, comparative trial. Cancer 98:1735-1744, 2003

22. Ruggieri P, Mavrogenis AF, Ussia G, Angelini A, Papagelopoulos PJ, Mercuri M: Recurrence after and complications associated with adjuvant treatments for sacral giant cell tumor. Clin Orthop Relat Res 468:2954-2961, 2010

23. Sar C, Eralp L: Surgical treatment of primary tumors of the sacrum. Arch Orthop Trauma Surg 122:148-155, 2002

24. Thangaraj R, Grimer RJ, Carter SR, Stirling AJ, Spilsbury J, Spooner D: Giant cell tumour of the sacrum: a suggested algorithm for treatment. Eur Spine J 19:1189-1194, 2010

25. Thomas D, Henshaw R, Skubitz K, Chawla S, Staddon A, Blay JY, et al: Denosumab in patients with giant-cell tumour of bone: an open-label, phase 2 study. Lancet Oncol 11:275280,2010

26. Todd LT Jr, Yaszemski MJ, Currier BL, Fuchs B, Kim CW, Sim FH: Bowel and bladder function after major sacral resection. Clin Orthop Relat Res (397):36-39, 2002

27. Tse LF, Wong KC, Kumta SM, Huang L, Chow TC, Griffith JF: Bisphosphonates reduce local recurrence in extremity giant cell tumor of bone: a case-control study. Bone 42:68-73, 2008

28. Werner M: Giant cell tumour of bone: morphological, biological and histogenetical aspects. Int Orthop 30:484-489, 2006

29. Xu W, Li X, Huang W, Wang Y, Han S, Chen S, et al: Factors affecting prognosis of patients with giant cell tumors of the mobile spine: retrospective analysis of 102 patients in a single center. Ann Surg Oncol 20:804-810, 2013

30. Zhang ZY, Fu CF, Yang YX, Wang LQ, Cui Y, Liu Y: Longterm outcomes following en bloc resection for sacral tumor: a retrospective analysis of 93 cases. Orthopedics 34:e403e407, 2011

\section{Disclosures}

The authors report no conflict of interest concerning the materials or methods used in this study or the findings specified in this paper.

\section{Author Contributions}

Conception and design: Xiao, Xu, Zhou. Acquisition of data: $\mathrm{Xu}, \mathrm{J}$ Wang, T Liu. Analysis and interpretation of data: Xu, Y Wang, J Wang, Yang. Drafting the article: Xu, Y Wang. Critically revising the article: Xu, Y Wang. Reviewed submitted version of manuscript: Xu. Statistical analysis: Xu, J Wang, W Liu, Zhou. Administrative/technical/material support: Xu, W Liu. Study supervision: Xiao, T Liu.

\section{Supplemental Information \\ Online-Only Content}

Supplemental material is available with the online version of the article.

Supplementary Figs. 1 and 2. https://thejns.org/doi/suppl/ 10.3171/2016.10.SPINE151197.

\section{Correspondence}

Jianru Xiao, Spine Tumor Center, Changzheng Hospital, Second Military Medical University, 415 Fengyang Rd., Shanghai 200003, China.email: jianruxiao83@163.com. 